\title{
Teaching Old Dogs "New" Grammar Tricks with Content-based Instruction: A Course Evaluation
}

\author{
Deron Walker \\ Department of Languages \& Literature at California Baptist University \\ E-mail: dwalker@calbaptist.edu
}

*Dr. X, Derrick, Macy, and Inland Empire University all represent pseudonyms to preserve the anonymity of the participants' identities.

Received: May 12, 2020

doi:10.5296/jse.v10i3.17204
Accepted: June 17, 2020

Published: August 1, 2020

URL: https://doi.org/10.5296/jse.v10i3.17204

\begin{abstract}
What do we do when we discover that a uniform body of research speaks with virtually one voice, boldly declaring that practically everything we have traditionally experienced in school and have ever been taught about teaching grammar has been consistently found to be largely ineffective? A California school teacher, continuing her professional development and studying a graduate level English course using "contextual approaches to grammar," might feel anxious, skeptical, or perhaps even relieved for the opportunity to be able to stop "teaching the book" in favor of exploring "new" methods and approaches, content-based instruction (CBI). This paper reports on a naturalistic inquiry in which a graduate level course instructor introduced this "new" approach and its "new" methods to his class of graduate student / teachers and encouraged them to make their own innovations to grammar instruction. As a result, both the numerical ratings and comments on course evaluations as well as the work submitted during the semester, indicated strongly that the beginning teachers and pre-service teachers taking this course learned a lot about teaching grammar more contextually, in a content-based manner. Thus, they were increasingly willing to try out those ideas when engaged in literary or writing instruction by the end of the course.
\end{abstract}

Keywords: Content-based instruction, pedagogical grammar, contextual 


\section{Introduction}

This paper presents the results of a naturalistic inquiry conducted in a graduate course at Inland Empire University emphasizing "contextual approaches to grammar." I will share some of the impressive ideas which the students came up with for teaching grammar and the course content that inspired and empowered them to create their own content-based grammar instruction. Through data collected in the self-reports of course evaluations and student-generated teaching philosophies, analysis of student lesson-unit plans, and course observations, I will share why early-career teachers, moonlighting as graduate students, overwhelmingly said they were "no longer afraid of grammar," found the course to be "very helpful...focused on context" and that a "normally dry subject" [grammar] became fun.

The course did not start without a bit of anxiety, however. In fact, the course began on opening night with a rendition of the failure of more than 50 years of traditional textbook and drill-oriented grammar instruction to reach sufficient numbers of children to make drill alone an acceptable instructional method (Braddock, Lloyd-Jones, et al., 1963; Elley, Barton, et al., 1976; Freeman \& Freeman, 2004; Krashen, 1998; Weaver, 1996). This is especially disconcerting when teachers are charged with the responsibility of reaching all of their students or as many of them as possible. It is a very uncomfortable feeling for a teacher of language arts to be told that the traditional methods of grammar instruction that she was raised with are not good enough, and she must not only learn but also actively develop a new way of teaching grammar for her students to succeed, at least to a degree approaching the challenging benchmarks of "No Child Left Behind" and the Common Core standards. While other nations may or may not have an official state or national mandate to worry about, it is an imperative for all advanced nations to educate all of their children proficiently in this age of globalization and technology.

\section{Traditional Grammar's Ineffectiveness}

Succinctly stated, Weaver (1996) has informed us that grammar rules are difficult to learn and even more complicated and cumbersome to apply. This is effectively illustrated by the Macauley studies in Scotland. After years of daily study in traditional-style identification, Macauley tested both elementary and secondary students on parts of speech recognition tests that were not unlike the kind of tests that are given as standardized tests in language arts in the United States. The results were appalling. Among a sample of 131 elementary school subjects $27.9 \%$ was the average score for correctly identifying parts of speech in sentences. The secondary students fared better $(62 \%)$, but even those results were below what would be commonly thought of as success rates (Freeman \& Freeman, 2004). This finding suggests that traditional grammar instruction by itself may not even be the most effective way to prepare for standardized tests, contrary to popular belief.

Another problem often cited in the literature on traditional grammar instruction is that it does not serve the purpose of increasing writing skill as is commonly believed. Krashen's (1998) review of research on traditional prescriptive teaching of grammar summed it up well, "Research on the relationship between formal grammar instruction and performance on measures of writing ability is clear: There is no relationship between grammar study and 
writing." (p.8) Krashen's finding is consistent with a multitude of other research on the topic. It has further been suggested by some that traditional grammar instruction could be harmful in writing instruction (Braddock, Lloyd-Jones, et al., 1963). How can that be? There are a couple of reasons: 1) it displaces instruction and practice in the process of composition and 2) it can raise anxiety levels among students that may cause them to put an unhealthy emphasis on correctness to the detriment of their rhetorical development and loss of voice as writers.

\section{3. “Teaching” Old Dogs 'New' Grammar Tricks}

Of course, despite all of the research, traditional grammar instruction that emphasizes prescription, parts of speech, isolated drills, and teaching the textbooks is still prevalent in many school systems not only in the U.S. but around the world as well. Weaver (1996) and Freeman and Freeman (2004) explained why:

- teachers are often unaware of the research

- $\quad$ school officials often do not trust research

- $\quad$ some find drill in grammar interesting

- $\quad$ some assume a correlation exists between writing, reading, and grammar skill

- $\quad$ teachers are often required and pressured to do so by parents and administrators

- $\quad$ though not for everyone, grammar drill may help some students

In fact, those are very good reasons for not abandoning traditional grammar instruction altogether. One does not need to eliminate all tradition either to improve his/her approach to teaching grammar in a language arts curriculum. It is quite possible to incorporate some traditional instruction in tandem with a content-based approach. Kolln and Gray $(2015,2016)$ and Weaver $(1996,1998)$ have offered teachers and aspiring teachers many resources and much assistance in reenvisioning prescriptive grammar through the lens of descriptive, functional, and rhetorical approaches.

Recent research has found that despite ongoing controversies over how to teach grammar (explicit-implicit, contextual/communicative-traditional/structural, etc.), there is a growing movement to restore grammar instruction to "its rightful place in the curricula" (Al Balushi, 2019, p. 42). From America to Australia, but especially in the UK and Australia, Jones and Chen (2012) discussed the urgent need for teacher-trainer programs to significantly upgrade pre-service teachers' knowledge about language (KAL) as well as their ability to contextually apply grammar functionally and rhetorically, moving beyond traditional prescriptive grammar drills in their pedagogical application. In fact, several sources have pointed to this need for teachers to upgrade their knowledge of grammar and grammar teaching methods in order to exercise their agency in developing a more positive attitude and more effective pedagogy concerning grammar instruction to fulfill state and Ministry of Education standards as applicable (Al Balushi, 2019; Hadjioannou \& Hutchison, 2010; Harper \& Rennie, 2008; Jones \& Chen, 2012). While the need for such pre-service training is widely recognized, few programs are actually meeting this need successfully. Unfortunately, many complications 
exist not only on the instructional level with knowledge about language (KAL) deficits among some pre-service teacher candidates and controversies about grammar method, but also at the curricular level as well. On a university program level, English departments are often preoccupied with the teaching of literature and its pedagogical applications while many Education colleges remain focused on learner diversity. Thus, many college programs produce pre-service teacher candidates that go through training programs where knowledge of language is fragmented and lacking in depth leaving teachers to fall back on prescriptive fundamentals where stronger teacher language skills and more contextualized approaches are needed (Harper \& Rennie, 2008).

Nevertheless, there are plenty of innovative approaches these days for teaching grammar such as using educational computer games (Kayan \& Adin, 2020). Simply contextualizing grammar instruction (Aziz \& Dewi, 2019) can both improve attitudes toward grammar instruction and achieve greater gains in academic achievement in learning grammar as well. In terms of writing instruction, whether it is with L2 writers in an ESL environment (Santana-Williamson, 2013) like the U.S. or an EFL context such as China (Wang \& Zhu, 2020), teaching grammar through writing definitely can improve student writing quality, rhetorically-speaking. In terms of grammar, syntax may become more sophisticated if not entirely accurate. In both of the aforementioned university writing situations, there were obvious writing benefits such as reduced anxiety, broadened thinking, more evidence and logic used (Wang \& Zhu, 2020) and improved ability to summarize, report, and synthesize information (Santana-Williamson, 2013).

As for improving pre-service teacher knowledge about language (KAL), Kolln and Gray's $(2015,2016)$ textbooks, in particular, have synthesized traditional grammar exercises and offered functional, descriptive and rhetorical advice for their application to writing and literature, which is what content-based instruction (CBI) is all about. Meanwhile, Weaver (1998) has compiled for dissemination many "new" and "innovative," diverse and creative, ideas for teaching grammar through literature and writing that can make dry old grammar concepts seem fresh and alive. In case the reader is wondering why I keep putting "new" and "innovative" in quotation marks, it is because these ideas, though fresh, are remarkably "un-new." The creative ideas found on image grammar, sentence composing, mini-lessons for grammar errors in writing, dialogue journals, etc. capitalize on theories regarding naturalistic language acquisition and process composition that have been around for some time. Notwithstanding, many of these ideas are "fresh" and "new" to teachers that come to conferences or attend graduate classes in the evening, such as the one in this study, looking for a little practical, pedagogical help. This is why the current article is being offered in order to further disseminate promising and worthwhile ideas on teaching grammar for language teachers of elementary, and especially, secondary and tertiary students.

\section{Method}

In a recent course taught at Inland Empire University's M.A. English program on teaching grammar in context, a qualitative approach was taken to see how early-career teachers and pre-service teachers would respond to the challenge to go beyond traditional grammar drills 
to create innovative grammar lessons involving content-based instruction (CBI). The course in question, Teaching Grammar in Context, was a graduate course in the English Department at Inland Empire University designed to balance the aforementioned need to upgrade or refresh the knowledge about the language, especially grammar concepts, and also provide contextual approaches for teaching grammar to students (Al Balushi, 2019; Hadjioannou \& Hutchison, 2010; Harper \& Rennie, 2008; Jones \& Chen, 2012). According to the course description and master syllabus, these two goals were somewhat evenly divided. Nevertheless, there was room for a professor to lean in one direction or the other (grammar knowledge or contextualized teaching methods). As previous instructors were literary professors and not trained linguists or certified language teachers, it is fairly likely that they may have leaned toward grammar knowledge. Dr. X, however, was both a trained linguist and certified teacher with significant non-literary teaching experience. Thus, the decision was made to lean more towards engaging in contextualized approaches to teaching grammar, content-based instruction $(\mathrm{CBI})$.

In terms of subjects, there were 13 graduate students enrolled in this course. Ten of the thirteen graduate students were already early-career teachers: 2 elementary, 2 middle, and 2 high school. Four of the teachers were university level instructors. The four university level instructors were actually graduate students at Inland Empire University teaching freshman writing while completing their master's degrees. They might be considered graduate assistants elsewhere but were categorized as adjunct part-time instructors at IEU. The class ratio between K-12 teachers and university level instructors would be considered fairly typical as this course was under the English pedagogy concentration though literature concentration students, especially those interested in teaching freshman writing at IEU, might take it to upgrade their pedagogical skills with composition. The number of students $(\mathrm{N}=13)$ was fairly robust enrollment as the class-size for this course typically ranged between 8 and 15 students per term. The data collection would involve professor notes and examination of course materials such as journal reflections, lesson / unit plans, and especially 3-5 page grammar philosophy essays and professor / course evaluations. The latter two measures came at the end of the semester and were reflective and critical thought-promoting by nature, allowing students opportunities for full reflection and critical thinking about what was taught in the course in regard to grammar pedagogy.

While it may be somewhat controversial to place strong emphasis on the student evaluations of teaching as a primary measure of teaching effectiveness, it may be equally asserted that such emphasis is not misplaced. A significant body of research exists indicating that mutual rapport between teachers and students (Corbett, 1991; Elbow, 2000; Murray, 2004) strongly correlates with teacher effectiveness in English classes. Also, recent research on teaching evaluations has strongly supported their use at the university level, even suggesting that they often do correlate with student learning and academic achievement in general (Boswell, 2016; Chitre \& Srinivasan, 2018; Gross et al., 2015; Kosir \& Tement, 2014; Quin, 2017; Serin, 2019). Professors at Inland Empire University have their teaching rated as "superior" ( $>95 \%$ 4s \& 5s), "excellent" (> 90\% 4s \& 5s), "good" (between 85 - 89\% 4s \& 5s), or "unacceptable $(<85 \% 4 \mathrm{~s} \& 5 \mathrm{~s})$. These course evaluations are taken very seriously by the university 
administration as the leading and nearly sole indicator of teaching success in the classroom, strongly influencing both retention and promotion. In the official tenure formula, for instance, the administration rates "teaching" as $60 \%$ of the stated formula while $20 \%$ is devoted to "research" and $20 \%$ to "service." Actually, most professors feel like teaching is really significantly more than $60 \%$ of the university administration's emphasis.

\section{Results}

The teaching philosophy assignments and lesson / unit plans were considered to be places to look to see if students were going to be willing to take what they learned from the course about contextualized, content-based instruction (CBI) and put it into their teaching practices. Given the small number of students $(\mathrm{N}=13)$, the teaching philosophies were analyzed by hand to look for themes that these beginning teachers emphasized as concepts that would be playing significant roles in their pedagogical practice in the future (See Table 1).

Table 1. Teaching Philosophy Themes

\begin{tabular}{|l|l|}
\hline Principle of Grammar Instruction & Number of Students \\
\hline Teaching grammar in context of writing & 10 \\
\hline Motivation & 7 \\
\hline Context (CBI) & 6 \\
\hline Writing and Literature both & 5 \\
\hline Incorporate into min-lessons & 5 \\
\hline $\begin{array}{l}\text { Teach Grammar through Reading in } \\
\text { general }\end{array}$ & 5 \\
\hline Peer editing with Writing & 5 \\
\hline Prioritize Feedback & 4 \\
\hline Applicability / Authentic & 4 \\
\hline Group Work & 4 \\
\hline Teacher Conferencing & 3 \\
\hline Discovery & 3 \\
\hline
\end{tabular}

Table 1 clearly illustrates that these graduate students (10-13) were significantly impressed that it is important to teach grammar within the context of student writing. This could take place in a variety of ways including modeling error patterns and how to fix them in written feedback on student papers, peer edits (5-13), quick pull-out lessons on grammar during teacher conferences (3-13), and workshops where select student sentences are grammatically analyzed in mini-lessons (5-13) and edited on the board. These sentences would need to be anonymous, volunteered or taken from a collection of Inland Empire University student sentences collected (with permission) from other similar class sections, which is Dr. X's personally preferred method. The important consideration is not to embarrass students by criticizing their work in front of the class, especially without their consent. A number of students also mentioned that teaching grammar through reading was important as well as using both writing and literature (5-13) to emphasize context (6-13). It is also clear that these and many other findings from the teaching philosophies (e.g. importance of discovery, 
authenticity, etc.) speak volumes to the power of motivating students with authentic opportunities to acquire English grammar.

Tables 2 and 3 delineate student responses to the course in terms of what they thought about the quality of instruction in Contextual Approaches to Grammar.

Table 2. Professor / Course Evaluations Quantitative

\begin{tabular}{|c|l|l|l|}
\hline Question & $\begin{array}{l}\text { Question } \\
\text { Mean }\end{array}$ & $\begin{array}{l}\text { Question St. } \\
\text { Dev. }\end{array}$ & $\begin{array}{l}\text { Professor } \\
\text { Score }\end{array}$ \\
\hline 1. Textbook / Course Materials & 4.9 & 0.29 & 5.0 \\
\hline 2. Value of Homework Assignments & 4.9 & 0.29 & 5.0 \\
\hline 3. Value of Lectures & 4.8 & 0.39 & 5.0 \\
\hline 4. Value of Class Discussions & 4.8 & 0.45 & 5.0 \\
\hline $\begin{array}{l}\text { 5. Professor's use of technological } \\
\text { resources }\end{array}$ & 5.0 & 0.00 & 5.0 \\
\hline $\begin{array}{l}\text { Substantiveness of course content / } \\
\text { depth and / or comprehension }\end{array}$ & 4.9 & 0.29 & 5.0 \\
\hline $\begin{array}{l}\text { Clear Communication of course } \\
\text { requirements in the Syllabus }\end{array}$ & 4.9 & 0.29 & 5.0 \\
\hline $\begin{array}{l}\text { Consistent and clear course grading } \\
\text { policies }\end{array}$ & 5.0 & 0.29 & 5.0 \\
\hline 9ntegration of Christiana perspective & 4.9 & 0.29 & 4.0 \\
\hline 10. Facilitation of critical thinking & 4.9 & 0.29 & 5.0 \\
\hline 11. Professor's organization of subject \\
matter
\end{tabular}

At Inland Empire University teaching is considered of prime importance, officially representing $60 \%$ of the tenure formula, perhaps even much higher unofficially. Professors are expected to get a minimum of $85 \%$ approval ( $4 \mathrm{~s}$ and $5 \mathrm{~s}$ ) from students as a minimum standard of proficiency in teaching. An approval rating of $95 \% 4 \mathrm{~s}$ and $5 \mathrm{~s}$ would be considered a "superior" mark in teaching. In this particular course on teaching grammar in context, Dr. X captured a remarkable $100 \%$ approval rating ( $4 \mathrm{~s}$ and $5 \mathrm{~s}$ ) on the 17 questions listed above in 
Table 2. Out of the 12 students who answered the evaluation questions, 176 responses recorded were rated as (5) "Excellent" (91.7\%). Only 16 were rated as (4) "Good" (8.3\%). No responses were rated in the three lower categories. Furthermore, 36.4\% of students reported putting "Extensive" effort into the course. Another $54.5 \%$ indicated that they made an average effort. Only 9.1\% suggested that they had put minimal effort into the course. By the numbers, this particular course was rated "Superior" by its students this term. This finding is further evidenced by the "average" to "extensive" amount of effort made by students as well as the comments below delineated in Table 3.

Table 3. Comments on Professor / Course Evaluations

\begin{tabular}{|c|c|}
\hline $\begin{array}{l}\text { Comment } \\
\#\end{array}$ & Remarks \\
\hline 1. & $\begin{array}{l}\text { "I am no longer afraid of grammar. I have a better understanding of } \\
\text { grammar and I like how Dr. X facilitated the course." }\end{array}$ \\
\hline 2. & $\begin{array}{l}\text { I greatly appreciated the thoughtful and focused criticism/feedback. I feel } \\
\text { that I have a firm grasp of grammar from a structural linguistics } \\
\text { perspective, and---probably more important---how to teach grammar from } \\
\text { k to postgraduate. We learned quite a number of excellent approaches and } \\
\text { strategies. Additionally, I enjoyed how Dr. X began each class with a praise } \\
\text { and/or prayers." }\end{array}$ \\
\hline 3. & $\begin{array}{l}\text { "Most of the class have taught for many years and already have much } \\
\text { experience with teaching grammar in the classroom. This made it difficult } \\
\text { for me at times because I don't have the extensive background in the } \\
\text { classroom. Instruction was given but some assumptions were made about } \\
\text { knowledge we should have had about things, for example lesson plans, and } \\
\text { I was under the assumption that either format was acceptable one was } \\
\text { preferred, which I found out upon the grading process---the two final } \\
\text { assignments could have been explained in more detail----the philosophy } \\
\text { paper and the grading student x paper." }\end{array}$ \\
\hline 4. & $\begin{array}{l}\text { "I really enjoyed the instructor and the course. I never thought I would } \\
\text { have fun in grammar class." }\end{array}$ \\
\hline 5. & $\begin{array}{l}\text { "The Prof. is very good and knows his staff well. I like the way he prayed } \\
\text { with us at the beginning of each class lesson. He is a prof. to be detained to } \\
\text { uplift the Christianity of the university." }\end{array}$ \\
\hline 6. & $\begin{array}{l}\text { "Very helpful class---was glad we focused on the contextual aspect---I will } \\
\text { take quite a bit of this content with me. Assignments were also very } \\
\text { practical to classroom use." }\end{array}$ \\
\hline 7. & $\begin{array}{l}\text { "Dr. X was an excellent instructor for this grammar class. His knowledge } \\
\text { of the context was excellent. He made a dry subject interesting." }\end{array}$ \\
\hline 8. & $\begin{array}{l}\text { "I really enjoyed the class discussions. I will incorporate many things I } \\
\text { have learned into my own teaching experience. You taught grammar with a } \\
\text { no pressure attitude, and I really valued that quality. I also enjoyed your } \\
\text { personal experiences and great sense of humor. Thank you for all your hard }\end{array}$ \\
\hline
\end{tabular}




\begin{tabular}{|l|l|}
\hline & work.” \\
\hline 9. & $\begin{array}{l}\text { I really enjoyed this class and feel so much more confident in my ability to } \\
\text { teach grammar. One suggestion would be to make sure you provide a break } \\
1 / 2 \text { way through. It's very hard to concentrate when I am so hungry." }\end{array}$ \\
\hline & \\
\hline
\end{tabular}

Both the numbers and comments indicated that these graduate students learned a lot about teaching grammar in more of a Content-Based Instructional (CBI) manner and enjoyed the experience as well. Overwhelmingly, students reported that they were "no longer afraid of grammar," found the course to be "very helpful...focused on context" and that a "normally dry subject" [grammar] became fun."

Both the quantitative (numerical approval ratings) and qualitative (comments) feedback from the student-generated professor / course evaluations indicated that this graduate seminar in content-based approaches to teaching grammar provided insightful and fun ways to teach grammar in a more authentic and practical manner. In addition, the students' key assignments also reflected that they were enthusiastically applying content-based instruction to their work in preparation of committing to such an approach pedagogically in their own classrooms. As readers saw in Table 1, a close-reading of student grammar teaching philosophy papers revealed that commitment to such themes was adopted by most of the student-teacher practitioners. As many as 10 of 13 students who were preparing to or already teaching emphasized the importance of teaching grammar through writing while nearly half focused on providing context for grammar instruction (6), using literature and writing both (5), reading (5) and the use of mini-lessons (5). These teaching philosophy papers provided convincing results that this graduate course compelled English teachers to start thinking beyond traditional drill exercises and commit to taking authentic context-based instructional approaches to grammar teaching. Many of the lesson / unit plans also provided compelling evidence that the student-teachers were thinking outside of the traditional box to experiment with content-based instructional approaches to grammar instruction as well. Two such plans by different established teachers at different levels will be offered here: elementary and secondary level.

\section{Derrick's Plan}

Derrick has already taught language arts for three years at a local elementary school in an urban setting. His unit plan was designed for $3^{\text {rd }}$ graders. About half of them do not speak English in the home as their first language. Derrick's plan proposes using literature and writing to teach and reinforce principles of grammar. He is using The Fox and the Moon to get students to be able to identify and form plural and possessive nouns and expand on their predicates, first by comprehending these structures in the story then producing them in the writing. These grammar structures provide sufficient developmental challenge for even native English speakers of that grade level but are often significantly more challenging for non-native (mostly Spanish speakers) English learners in Derrick's class. After reading the story and working on comprehending the aforementioned grammar forms, Derrick's class is to be tasked with a creative writing assignment to write narrative fiction with a super hero 
theme. They will engage in all phases of the writing process with an eye on reinforcing the grammar of the unit. As a reward they look to publish their stories in a class journal. Derrick is actually in the process of implementing the unit in his $3^{\text {rd }}$ grade class as of the time of this writing and is very excited about this work-in-progress.

\section{Macy's Plan}

Macy has been teaching $9^{\text {th }}$ grade locally for five years. Macy's plan uses Elie Wiesel's Night, a powerfully written short autobiographical account of the horrors that the author and his father experienced in the concentration camps of World War 2. In addition to the literary value of reading a very moving work, grammatically speaking, Macy focused on adjectives and adverbs in her unit. When reading Night, students were tasked with identifying adjectives and adverbs. The gap between reading and writing was then bridged with note taking and journal writing. At this point, the grammar focus shifted to not only these descriptive words in text but then using more adjectives and adverbs in one's own writing. In this unit, there was definitely a focus on content-based instruction and meaning. There is even an opportunity to write across the curriculum as social studies and English connect with this unit.

Both of these students and young teacher-practitioners, Derrick and Macy, offered unit plans that effectively put ideas learned in the course about teaching grammar contextually, into content-based instruction. These models were some of the better examples of the kind of work that most of the students in the class were putting forth. Also, Derrick and Macy used their positions in the local K-12 school system to implement their ideas with great optimism. With content-based-instruction, teacher-practitioners are limited only by their own imagination as to how they can go beyond traditional direct instruction and drill exercise teaching of grammar. As Macy elaborated in her teaching philosophy paper,

I chided myself every year [of teaching] for not focusing enough on grammar when my students did not do well on the semester final and California State Test. After taking this class, I realize what my colleagues espoused [direct instruction] may not even be the most efficient or even the most effective way to help students improve their grammar. (Macy's teaching philosophy paper)

As Macy indicated, she did not feel confident teaching grammar the traditional old-fashioned way and did not feel like it was effective, but she really had no idea what to do in place of traditional direct instruction and drill before taking this graduate class on teaching grammar in context with content-based instruction. As Macy continued,

Before this school year, it had been a while since I had taught English. When I made my lesson plans every week, grammar instruction was in the back of my mind but I hesitated to incorporate it because I did not feel confident in my ability to teach it. I also knew from experience that most students do not enjoy learning it or spending the time doing the exercises in grammar books. This also kept me from pursuing extensive grammar lesson designs (Macy's teaching philosophy paper). 


\section{Discussion}

It is clear, then, from the data analyzed (teaching philosophy papers, lesson / unit plans, and professor / course evaluations) that the graduate students who also served as early career teachers grew in confidence and demonstrated positive attitudes toward grammar and seemed more than willing to try out contextual, content-based instructional approaches in their own classrooms. Such an increase in positive attitude is important to cultivate in a pedagogical grammar course for teachers as it has been found that increased positive attitude about grammar correlates with increased grammar knowledge (Al Balushi, 2019). The writings of more than a few student-teachers on their teaching philosophy papers and especially Macy's testimony, along with many of the specific comments in Table 3 from the student-teachers on the course evaluation indicated that this course had helped them to overcome many of their anxieties about grammar both in terms of knowledge about the language (KAL) and teaching technique. This is important because previous research has strongly indicated that knowledge about language has been fragmented among beginning teachers, more contextualized approaches to pedagogy are needed and that teachers are more willing to apply contextual, content-based instruction (CBI) to grammar when their knowledge about the language, especially grammar, increases (Al Balushi, 2019; Hadjioannou \& Hutchison, 2010; Harper \& Rennie, 2008; Jones \& Chen, 2012; Onlan, 2018).

Thus, the Contextual Approaches to Grammar class taught at Inland Empire University and courses like it are attempting to meet the profound curricular need to refresh / upgrade the knowledge about language, especially grammar, and the ability to pedagogically implement contextualized grammar lessons to their students more effectively. As current research has suggested, while programs, teachers and instructors are attempting to meet this need, a lot more remains to be done (Al Balushi, 2019; Hadjioannou \& Hutchison, 2010; Harper \& Rennie, 2008; Jones \& Chen, 2012). Currently very few programs are successfully meeting these needs. From a program perspective, one of the most compelling reasons that cause classes like the aforementioned to be in such short supply is that English programs tend to focus their resources on teaching literature while Education colleges tend to emphasize learner diversity (Harper \& Rennie, 2008). In addition, Smagorinsky and his colleagues (2011) found the issue to be further complicated in America by the recent trend for teachers to be tightly constrained to rigidly adhering to the standards set forth in No Child Left Behind and Common Core guidelines that leave teachers much less flexibility to develop creative lesson plans using contextualized content-based instruction. Smagorinsky et al. (2011) followed the professional development of a beginning teacher over the course of two years finding that her preparation "provided little foundation of conceptually grounded approach to [grammar] instruction" (p. 274). The program offered more emphasis on teacher-mentoring, "experimentation and repair than on providing upfront pedagogical support" (p.274). Pressure to not only teach standards, but to also teach to the test and standardize instruction rigidly can stifle teacher creativity and inhibit instructors from engaging in the best research-based practices (D. Walker \& S. Walker, 2019). In this case, constrained teachers would be more likely to emphasize traditional structural drill rather than contextualized, content-based instructional approaches. 
Nevertheless, some programs, teachers and researchers are implementing contextualized, content-based instructional approaches with success. For instance, Halstead (2019) taught grammar in London, U.K. in the context of authentic texts in her classes of eight and nine year olds to make their writing more purposeful and engaging. Specifically, she chose to emphasize using verbs for invigorating action description in legends through the models of Beowulf by Michael Morpurgo and The Saga of Erik the Viking by Terry Jones. Halstead's (2019) writers successfully expanded their sophistication of syntax, improved their vividness of action description and upgraded their ability to develop characters through more skillful use of dialogue. Halstead's (2019) action research approach to contextualizing grammar instruction in literature was quite similar to Derrick's approach in this study in using authentic literature to expand $3^{\text {rd }}$ graders' use of predicates for more elaborate description and narration. Although working with high school $9^{\text {th }}$ graders, Macy, in the current study also used authentic literature, focusing on adjectives and adverbs for better description. All of the aforementioned teachers enjoyed promising results in using authentic literature to contextualize grammar instruction, especially expanding syntax and improving the descriptive, narrative value of student writing by engaging literary models with a content-based approach.

Naturally, there are a number of other ways to contextualize grammar instruction in a naturalistic, creative, content-based manner. Educational computer games can be used to teach grammar at any level (Kayan \& Adin, 2020). In addition to Halstead (2019) and Derrick in this study using authentic literature to model and teach better description to elementary school writers, Macy took a similar approach at the secondary level. At the university level, there have been a few more approaches that have demonstrated success at the tertiary level. Sarac (2018), for instance, successfully employed a task-based approach with university students learning English in Turkey. In a first-year English language course, the task-based learning used with the experimental group outperformed the control group who received form-focused grammar instruction. In terms of university level writing instruction, studies have convincingly demonstrated that L2 writers in an ESL environment (Santana-Williamson, 2013) as in the U.S. or an EFL situation as in China (Wang \& Zhu, 2020) that teaching grammar through writing can improve student writing quality, rhetorically-speaking. In terms of grammar, syntax may become more sophisticated if not entirely accurate. In these studies of university writing instruction, teaching grammar through student writing reduced anxiety, broadened thinking, increased the use of evidence and logic used (Wang \& Zhu, 2020) and improved ability to summarize, report, and synthesize information (Santana-Williamson, 2013).

\section{Conclusion}

In response to their introduction to content-based instruction (CBI), Inland Empire University graduate student / teachers generated their own lesson-unit plans and grammar teaching philosophies that sought to build upon methods and approach to grammar instruction discussed in the course. The grammar pedagogy covered in the course was fresh, inspiring, and seemingly innovative because the approach and methods were previously unknown to the teachers. This was due, in part, to insufficient dissemination of these practices through the 
educational system. Instead, schools typically cling to traditional but ineffective methods involving drill and teaching the textbook which render instruction that cheats toward teaching to the standardized test. This graduate course on teaching grammar in context was fun and exciting as well as instructive because the students were willing to open their minds and hearts to it and try out the ideas they learned. Many of the concepts from this course have been put into practice by the graduate students / teachers and new ideas are being created from the results.

The problem with creating an effective grammar pedagogy is one of overreliance on old, familiar, comfortable, but ineffective methodology. As Gardner (1993) has instructed us, everyone has their own talents, interests, learning styles, and, yes, intelligences. In the $21^{\text {st }}$ century, we must appeal to as many students as we can to be effective practitioners of the art of teaching. "New" ideas are out there already waiting for us. The problem, then, is not so much one of innovation but dissemination. We need to be willing to learn from established schools of thought in naturalistic language acquisition and process composition theory to form a meaningful, content-based grammar instruction that goes beyond mere drill exercises and teaching textbooks. We need to teach children and adult learners in ways that motivate, captivate their attention, and help them to see the function, meaning, and purpose behind tired old prescriptive concepts of grammar in order to be successful in our profession.

\section{References}

Al Balushi, K. (2019). The relationship between TESOL teachers' attitudes toward grammar teaching and their grammatical knowledge. Advances in Language and Literacy Studies. 10(3), 42-47. https://doi.org/10.7575/aiac.alls.v.10n.3p.42

Aziz, I.N., \& Dewi, Y.A.S. (2019). The implementation of context teaching and learning on English grammar competence. Alsuna 2(2), 67-95.

Boswell, S.S. (2016). Ratemyprofessors is hogwash (but I care): Effects of Ratemyprofessors and university-administered teaching evaluations on professors. Computers in Human Behavior, 56, 155-162. https://doi.org/10.1016/j.chb.2015.11.045

Braddock, R., Lloyd-Jones, R., et al. (1963). Research in written composition. Urbana, IL: National Council of Teachers of English.

Chitre, M, \& Srinivasan, D. (2018). Evaluating teaching effectiveness using quantitative student feedback. Paper presented at International Conference on Teaching Assessment and Learning for Engineering, 155-160. https://doi.org/10.1109/TALE.2018.8615171

Elley, W., Barton, I., et al. (1976). The role of grammar in a secondary school curriculum. Research in the Teaching of English, 10, 5-21.

Freeman, D. E., \& Freeman, Y. S. (2004) Essential linguistics: What you need to know how to teach. Portsmouth, NH: Heinemann, 2004.

Gardner, H. (1993). Multiple intelligences: The theory in practice. New York: Basic Books. 


\section{$\triangle$ Macrothink}

Gross, J. Lakey, B., Lucas, J.L., LaCross, R., Plotkowski, A.R., \&Winegard, B. (2015). Forecasating the student-professor matches that result in unusually effective teaching. British $\begin{array}{lllll}\text { Journal of } & \text { Educational } & \text { Society, } & 85,\end{array}$ https://doi.org/10.1111/j.2044-8279.1949.tb01605.x

Hadjioannou, X., \& Hutchison, M.C. (2010). Putting the G back in English: Preparing pre-service teachers to teach grammar. English Teaching Practice and Critique, 9(3), 90-105.

Halstead, R. (2019). Teaching grammar creatively. English 67, 4-11.

Harper, H., \& Rennie, J. (2008). 'I had to go out and get myself a book on grammar': A study of pre-service teachers' knowledge about language. Australian Journal of Language and Literacy, 32(1), 22-37.

Jones, P., \& Chen, H. (2012). Teachers' knowledge about language: Issues of pedagogy and expertise. Australian Journal of Language and Literacy, 35(1), 147-168.

Kayan, A., Aydin, S.A. (2020). The effect of computer-assisted educational games on teaching of grammar. World Journal of Education, 10(1), 117-133. https://doi.org/10.5430/wje.v10n1p117

Kolln, M.J., \& Gray, L.S. (2016). Rhetorical grammar: Grammatical choices, rhetorical effects ( $8^{\text {th }}$ edition). New York: Longman Publishing.

Kolln, M.J, \& Gray, L.S.(2015). Understanding English grammar( $10^{\text {th }}$ edition). Needham Heights, MA: Allyn \& Bacon.

Kosir, K., \& Tement, S. (2014). Teacher student relationship and academic achievement: A cross-lagged longitudinal study of three different age groups. European Journal of Psychology of Education, 29, 409-428. https://doi.org/10.1007/s10212-013-0205-2

Krashen, S. (1998). Teaching grammar: Why bother? California English, 3(3), 8.

Quin, D (2017). Longitudinal and contextual associations between teacher-student relationships and student engagement. A systematic review. Review of Educational Research, 87, 345-387. https://doi.org/10.1177/002205741808701427

Onalan, O. (2018). Non-native English teachers beliefs on grammar instruction. English Language Teaching, 11(5), 1-13. https://doi.org/10.5539/elt.v11n5p1

Santana-Williamson, E. (2013). Implementing task-oriented content-based instruction for first-and-second generation immigrant students. California TESOL Journal, 24(1), 79-97.

Sarac, H.S. (2018). Completing the task procedure or focusing on form. Contextualizing grammar instruction via task-based instruction. College Quarterly 21(1).

Serin, H. (2019). Student evaluations of teaching effectiveness: An instrument to increase teaching quality in higher education. International Journal of Social Sciences and Educational Studies, 5(4), 168-173. https://doi.org/10.23918/ijsses.v5i4p168 


\section{Macrothink}

Journal of Studies in Education

ISSN 2162-6952

Smagorinsky, P, Wilson, A.A, \& Moore, C. (2011). Teaching grammar and writing: A beginning teacher's dilemma. English Education 43(3), 262-292.

Walker, D., \& Walker, S.H. (2019). Empowering care in the inner-city: Meeting standards with high expectations. Educational Review. https://doi.org/10.1080/00131911.2019.1619519

Wang, C, \& Zhu, L. (2020). Effects of content-based communicative language teaching in university English writing classes. International Forum of Teaching and Studies, 16(1), 32-37.

Weaver, C. (1996). Teaching grammar in context. Portsmouth, NH: Boynton/Cook. https://doi.org/10.2307/820502

Weaver, C. (1998). Lessons to share on teaching grammar in context. Portsmouth, NH: Heinemann. 